\title{
Healer, Reveal Thyself
}

\author{
Andrés Martin ${ }^{1} \mathbb{B}$
}

Received: 3 September 2021 / Accepted: 21 October 2021 / Published online: 9 November 2021

(c) Academic Psychiatry 2021

No hour of life is wasted that is spent in the saddle.

\section{—Winston Churchill}

Individuals with mental illnesses and those of us who care for them are not that different from one another. We may differ in quality, but not in kind; we are the warp and the weft of the selfsame human fabric. What we do for our patients is not as important as who we are with them. But in being with them, how many of us share our fallibility, our vulnerability, our imperfection-more to the point: how many of us share our own experience being on "their" side of the aisle? Not nearly enough. We have been too caught up in a maladaptive search for perfectionism and infallibility. A quest that has zapped the joy out of the calling for so many, not to mention snuffed the life of a disproportionate number of physicians who have died by suicide [1].

Sharing such personal information with those under our clinical care or training oversight is understandably a bridge too far for many. The very words we use are telling: "disclosure" and "self-disclosure," terms with undertones of sinister actions, of crimes confessed, of taxes finally filed. Why disclose rather than simply share? And when sharing, why only about lived experiences safely relegated to a circumscribed past, rather than about the living ones that shape our days even after diagnoses have been treated and hardships overcome? When it comes to mental health, little of this state of affairs is due to the facile explanation of breaches in privacy. It is simpler than that. And more painful. It is because of stigma [2].

The most potent antidote to the exclusionary, distancing, and shaming ways of stigma is social contact with members of the ostracized group [3]. It is we, imperfect healers, the aching and the recovering among us, those of us who have experienced mental illness while dedicating our professional lives to improving the lot of others, it is we who can do

Andrés Martin

andres.martin@yale.edu

1 Child Study Center, Yale School of Medicine, New Haven, CT, USA so much. As experts synergized by both professional and personal experience, we have an opportunity, if not a moral obligation, to bring us closer, to demonstrate that no one is truly alone. Sharing is effective not as a confessional for the revealer, but as a salve for the informed.

There is no mandate to open one's innermost self to others- to each their own. Those of us who decide to share our living experiences can determine the radius of our intended reach and the concentric ripples that will surely follow: our loved ones, our patients, our colleagues, our guild, our community. It would be disingenuous to claim that sharing candidly is entirely free of risk. Friends may distance themselves or offer unwelcome pity; acquaintances may shun or avoid us; colleagues may retreat in discomfort; patients or superiors may lose confidence; gossipmongers, social media influencers, or the press may distort in ways that make it hard to put the horse back in the barn. And yet, the proposition may be best phrased in the reverse: what are the possible downsides of not sharing?

Missed opportunities for bridging the divide, is what. Every instance of genuine sharing is a generous offering that opens oft-relieving conversations, that gives permission to share in kind, and that more often than not brings closeness and strengthens relationships-including those with our patients. Sharing reveals that "we" are not that different from "them," not all that removed and safely ensconced away on a higher doctorly plane. Sharing the trajectory of our psychopathology lays bare that this is personal, that it matters, and that this is not a theoretical enigma to crack through the tools of our trade. Sharing reveals us as the equestrians that we are: we have a horse in this race.

My own horse threw me off the saddle for the first time when I was a child. By the time I was a grown-up man, the bruises and fractures from five lifetime falls had healed. For years, I could only observe my horse from afar: Melancholia, out on its pasture. My fearful respect for the steed kept me well out of its reach, but I rarely went long not thinking about it. Well into middle age I finally mustered the courage to share with friends and colleagues my checkered trajectory on horseback $[4,5]$. I even partook with some of my patients, whenever conducive to their recovery rather than 
my catharsis. I was stunned by the reception I received, by the compassionate interest from so many out on the same field, by the warm welcome as a card-carrying team member-a big step up from my solo rider status. Not that long ago I was thrown off once again, in a totally different and unexpected direction this time- -turns out my horse is part hippomanic roughstock (o ï $\pi$ os ["hó híppos"] being the Greek noun for "horse").

Whether you have bobbed, bounced, or bucked off an untamed bronco; whether your jumping has been more gauche than dressage; and regardless of how many times you may have been ejected from the saddle, I trust that you have found your way back on it. I can only wish on you to have tamed your beast, and that you can now walk, canter, trot, or gallop astride it as you wish. It is not for me to say whether and which of your adventures to share: only you can decide. But consider what took me way too long to learn: welcome, embrace, celebrate, and draw knowledge, connection-even pride-from your special membership, from a superpower you may not have realized can make you a better healer.

Giddy up then. Enjoy the ride, and more than contemplating its trajectory, speed, or destination, allow yourself to share the vistas granted by as few or as many furlongs covered during the unwasted time spent in your saddle.

\section{Declarations}

\section{Ethics Approval N/A}

Disclosures The author states that he has no conflict of interest.

\section{References}

1. Legha RK. A history of physician suicide in America. J Med Humanit. 2012;33:219-44.

2. Hinshaw SP. Another kind of madness: a journey through the stigma and hope of mental illness. St. Martin's Press; 2017.

3. Thornicroft G, Mehta N, Clement S, Evans-Lacko S, Doherty M, Rose D, et al. Evidence for effective interventions to reduce mental-health-related stigma and discrimination. Lancet. 2016;387:1123-32.

4. Martin A. Setting the River on Fire: A Study of Genius, Mania, and Character, and This Close to Happy: Reckoning with Depression (Book Forum). J Am Acad Child Adolesc Psychiatry. 2018;57:61-4.

5. Martin A, Chilton J, Paasche C, Nabatkhorian N, Gortler H, Cohenmehr E, et al. Shared living experiences by physicians have a positive impact on mental health attitudes and stigma among medical students: a mixed-methods study. J Med Educ Curric Dev. 2020;7:1-9.

Publisher's Note Springer Nature remains neutral with regard to jurisdictional claims in published maps and institutional affiliations.

Funding This work was supported by the Riva Ariella Ritvo Endowment at the Yale School of Medicine. 